\title{
Article
}

\section{Is composting worm availability the main barrier to large-scale adoption of worm- based organic waste processing technologies?}

Furlong, Claire, Rajapaksha-mudiyansela, Nalika, Butt, Kevin Richard and Gibson, Walter

Available at http://clok.uclan.ac.uk/18809/

Furlong, Claire, Rajapaksha-mudiyansela, Nalika, Butt, Kevin Richard ORCID: 0000-0003-0886-7795 and Gibson, Walter (2017) Is composting worm availability the main barrier to large-scale adoption of worm-based organic waste processing technologies? Journal of Cleaner Production, 164 . pp. 10261033. ISSN 0959-6526

It is advisable to refer to the publisher's version if you intend to cite from the work. http://dx.doi.org/10.1016/j.jclepro.2017.06.226

For more information about UCLan's research in this area go to http://www.uclan.ac.uk/researchgroups/ and search for < name of research Group>.

For information about Research generally at UCLan please go to http://www.uclan.ac.uk/research/

All outputs in CLoK are protected by Intellectual Property Rights law, including Copyright law. Copyright, IPR and Moral Rights for the works on this site are retained by the individual authors and/or other copyright owners. Terms and conditions for use of this material are defined in the policies page. 


\section{Is composting worm availability the main barrier to large-scale adoption of worm-based organic waste processing technologies?}

Claire Furlong ${ }^{a, *}$, Nalika S. Rajapaksha ${ }^{b}$, Kevin R. Butt ${ }^{\mathrm{b}}$ and Walter T. Gibson ${ }^{\mathrm{c}}$

a IHE Delft Institute for Water Education, Westvest 7, 2611 AX Delft, The Netherlands

b University of Central Lancashire, Preston, Lancashire PR1 2HE, United Kingdom

c Bear Valley Ventures Ltd, Braeside, Utkinton Lane Cotebrook, Tarporley, Cheshire CW6 0JH, United Kingdom

*Corresponding author

Abstract

Organic waste is the largest typology of waste generated globally, which if untreated, can causes environmental pollution and be a public health risk. The worm-based processing of organic waste is known as vermicomposting and is recognized as a sustainable approach for the management of organic waste streams. Although this technology has been around since the 1970s and many different organic wastes have been successfully processed via vermicomposting, this technology has not been widely adopted at national or international levels. This paper explores the hypothesis that the availability of composting worms is the reason for low uptake of this technology. A market analysis of composting worm farm (vermiculture) businesses in two countries (South Africa and India) was undertaken to explore the hypothesis. It was found that the Indian market had the capacity to supply over 70,000 kg of worms per month, whilst for the South Africa market this was $3000 \mathrm{~kg}$. Both markets have the capability to increase production by two-fold or more. Overall, the study concludes that worm supply is not a barrier to the scaling-up of worm-based technologies in either country. Additionally, these countries show the potential to assist development of wormbased systems in neighboring countries through export of composting worms.

Keywords: Composting worms; India; South Africa; Vermicomposting; Vermifilters; Vermiculture 1 Introduction

Organic waste is defined as any biodegradable waste that originates from animal or plant sources. Organic waste streams include sewage and fecal sludge, agricultural waste, food processing waste, and a fraction of municipal solid waste and it is the largest typology of waste generated globally. It accounts for the largest fraction of municipal solid waste; it has been estimated that globally 598 million tonnes of organic municipal solid waste are generated annually (Hoonweg and Bhada-Tata, 2012). The authors estimate that human population produces 800 million tonnes of organic waste annually, in the form of feces. This waste requires treatment to process and recycle nutrients, and to reduce the negative environmental impact when released into the environment. Additionally, unplanned release of unprocessed organic waste can pose a public health risk due to the spread of pathogens. Although difficult to quantify, it is believed that a majority of the world's organic waste goes untreated, with an estimated 350 million tonnes of untreated human feces annually discharged into the environment.1 Therefore, there is an urgent need for the large scale adoption of sustainable organic waste processing technologies.

Worm-based processing of organic waste is known as vermicomposting, a process developed in the late 1970s. This term did not appear in scientific literature until 1980, but now an extensive body of 
research now exists. Scientific interest in this organic waste processing technology has grown rapidly e.g. only seven papers were published in the 1980s, but over 338 have already been published this decade. 2 Vermicomposting has now been used to transform a wide range of organic wastes, from agricultural residues (Lim et al., 2015) and animal wastes (Lalandera et al., 2015), plant waste (Abassi et al., 2015) food wastes, municipal solid waste (Singh et al., 2011a) through to sewage sludge (Sinha et al., 2010; Yadav and Garg, 2011) and industrial wastes (Singh et al., 2011b).

Vermicomposting is a highly attractive approach for the treatment of organic waste due to low investment cost and the speed of processing, compared with other waste treatment technologies (Abbasi et al., 2015; Lim et al., 2016). Additionally, the nutrients in the organic waste are recycled into a high value soil amendment known as vermicompost (Lim et al., 2014, 2016; Wu et al., 2014). Recently there has been renewed interest in this technology (Abbasi et al., 2015; Jiang et al., 2016; Lim et al., 2014, 2016), this due to the inherent sustainability of the technology. Earthworms are known to sequester carbon through stabilization, hence their action mitigates climate change (Zhang et al., 2013). Furthermore, no methane is produced during vermicomposting as it is an aerobic process and greenhouse gas emissions are significantly lower compared with conventional composting (Komaketch et al., 2015).

An area which is developing rapidly and has huge potential for global impact is the use of vermicomposting in the sanitation sector. Vermicomposting of sewage sludge was one of the first wastes to be researched (Edwards, 2011) with this process being utilized selectively in the USA and Australia (Sinha et al., 2010). More recently, researchers have been exploring the use of vermifilters (biological filters containing worms) for the treatment of sewage sludge with high water content (Zhao et al., 2010) and wastewater (Jiang et al., 2016, Kadam et al., 2009; Li et al., 2009). Additionally, a small-scale vermifilter for treating fecal sludge at a household level has been developed and trialed for use in low-to middle-income countries (Furlong et al., 2014, 2015, 2016). Worm-based technologies therefore have the potential to aid the global sanitation crisis. This approach is thought to be particularly appropriate for low- and middle-income countries, as it offers a sustainable, cost effective and ecological approach for effective management of organic waste including human excreta (Zhao et al., 2010; Huang et al., 2013). Additionally, the potential markets for these technologies are huge as it is estimated that 2.5 billion people lack access to improved sanitation (WHO/UNICEF, 2012) and approximately 1.8 billion people rely on basic pit latrines (Graham and Polizzotto, 2013).

Although trials of vermicomposting organic waste have been ongoing since the 1970s, this technology has not been widely implemented. Having an appropriate worm species, or combination of species, is a key determinant for scaling-up of any worm-based organic waste processing technology. The types of worms used in these processes are known as composting worms and are naturally found in the organic soil horizon, in or near the surface litter, and feed on organic matter. There are many species of composting worms, and some of the most commonly farmed species and their characteristics are provided in Table 1. 
Table 1 Selected aspects of the biology of composting worms (adapted from Dominguez and Edwards, 2011).

Parameter

Color

Adult size $(\mathrm{mm})$

Mean adult mass $(\mathrm{g})$

Time to maturity (days) 28-30

Number of cocoons/day

$0.35-0.5$

Incubation time (days)

$18-16$

Hatching viability (\%)

$70-80$

Number of worms/cocoons2.5-3.8

Life cycle (days)

45-51

Temperature range (oC)

0-35

Optimal temperature (oC) 25

Moisture range (\%)

70-90

Optimal moisture (\%)
E. andrei

E. eugeniae

P. excavates

Reddish brownReddish brown

$4-8 \times 50-1005-7 \times 80-190 \quad 4-5 \times 45-70$

$0.55 \quad 2.7-3.5 \quad 0.5-0.6$

21-28 40-49 28-42

$0.35-0.5 \quad 0.42-0.51 \quad 1.1-1.4$

$18-16 \quad 12-16 \quad 18$

72

75-84

90

$2.5-3.8$

$2-2.7$

$1-1.1$

$45-51 \quad 50-70 \quad 40-50$

0-35 $\quad 16-30 \quad 25-37$

25

25

$>25$

70-90 70-85

$80-85 \quad 80$

The commercial worm farming (vermiculture) industry has never been fully studied and little information is available concerning composting worm supply capabilities at a national level for any country. The aim of this research was to determine if worm supply represents a barrier to large-scale adoption or scaling-up of worm-based organic waste processing technologies. This paper evaluates the current vermiculture markets and the potential for scaling-up vermicomposting technologies in two countries, India and South Africa. It also evaluates the ability of these markets to supply composting worms for a novel worm-based technology.

\section{Methodology}

\subsection{Country selection}

India and South Africa were chosen as they are known to have a history of vermicomposting (Kale, 2011; Munroe, 2004) and therefore thought to have well-developed vermiculture industries. India is thought to be the World's largest producer of vermicompost, it is widely reported that the affiliates of the Morarka Foundation produce over 50,000 tonnes of vermicompost per year. The focus in India has been on the production of vermicompost to use in small scale agriculture, rather than waste processing. This may change as vermicomposting is being nationally promoted as an official technology for solid waste management under the Clean India Mission (Swachh Bharat Mission launched in 2014). In South Africa the focus in on vermicompost production for gardens and small scale agriculture, and small scale decentralized waste processing i.e. winery or farm waste etc. There is no national program promoting this technology in South Africa. 
Additionally, both countries generate significant amounts of municipal solid waste. India generated 109,589 tonnes per day $(0.3 \mathrm{~kg} / \mathrm{capita} / \mathrm{day})$ and South Africa generated 53,425 tonnes per day ( $2 \mathrm{~kg} /$ capita/day) in 2012, with between 15\% an 35\% of this being organic waste (Department of Environmental Affairs, 2012; Hoonweg and Bhada-Tata, 2012). As the organic fractions are largely unmanaged this leads to significant greenhouse gas emissions. This waste stream accounts for $1 \%$ in India and $4 \%$ in South Africa of the total greenhouse gas emissions in each country (Hoonweg and Bhada-Tata, 2012). Additionally, a majority of both populations use onsite sanitation which leads to vast amounts of fecal sludge that needs to be treated before it is disposed of in the environment. South Africa alone produced 673,360 tonnes of fecal sludge in 2011, which far exceeds the amount of organic municipal waste generated in this country (Department of Environmental Affairs, 2012). Hence both were considered to be good potential markets for novel vermicomposting technologies.

Two markets (countries) were chosen so that a comparison between them could be drawn. This was made simpler as they were assumed to be independent markets; due to geographic distance they were unlikely to have an overlapping customer base. Furthermore, having examples on separate continents allowed for an assessment of the potential growth through exportation in two distinct geographical areas. Additionally, English is an official language and widely spoken in both countries, meaning that no translation was required.

\subsection{Data collection}

Businesses were identified through extensive web-based searches using the following terms; "vermiculture; worm farm; vermicompost; composting worm(s)" together with the county name (India or South Africa). The data collected was collated into supplier directories for each country, which included contact details for each business. A survey was then developed to gather detailed information from each company listed in the directory. It covered composting worm supply capabilities (i.e. worm species farmed, capacity, cost of worms, potential for expansion and questions on worm cocoons (egg capsules), as they are lighter and more robust, so would be easier to transport and export than live worms. The final survey amounted to three A4 pages and took approximately 20 min to complete.

Stratified sampling of all companies listed by email was employed. Due to the relatively few businesses identified in South Africa, snowball sampling was used to target other local vermiculture businesses. An electronic survey was not appropriate, due to intermittent internet connectivity and major problems with spam emails that contain suspicious links in both countries. The final survey was attached to an email, which introduced the researchers and the aim of the study. Therefore, email was chosen as the method of survey distribution, as all companies had an online presence (i.e. webpage or contact details listed on the internet) and an email address. Further email, online or telephone contact was attempted if a response was not initially gained.

The responding companies were anonymized and results presented were critically evaluated. Analysis included an assessment of each country's ability to take a novel worm-based technology to scale. As the known mass of worms is required to make this assessment, the "Tiger Toilet" (a wormbased sanitation system) was chosen as $2 \mathrm{~kg}$ of worms is required per unit (e.g. Furlong et al., 2016). Additionally, sustainable onsite sanitation is an issue in both countries. India has $35 \%$ improved sanitation coverage (as defined by the Millennium Development Goals 2005), while South Africa has $74 \%$ coverage (WHO/UNICEF, 2012). Therefore, both countries represent significant markets for this technology and other worm-based sanitation technologies.

3 Results and discussion 
Table 2 shows that there are approximately four times as many vermiculture business in India compared with South Africa. The total land area and population of India are respectively 2.4 and 23 times higher than South Africa (The World Bank, 2015) and the survey findings and numbers clearly reflect these differences. It is believed that the reported findings significantly underestimate the capacities in both countries, although the response rate was relatively high ( $>50 \%$ in both countries, Table 2), only businesses that had an online presence were targeted in this study.

Table 2 Number of companies identified, contact and response rates.

Number of companies

Identified via the internet

Contacted via email

Completed the survey

Number of vermiculture businesses 15
India South Africa

8121

$48 \quad 23 a$

2616

a Including two businesses identified via snowball sampling.

In India only 48 of the 81 companies identified online were sent surveys, as email addresses for the remainder could not be found. Of the non-respondents $(n=22)$ in India, 14 confirmed by telephone that worm farming was their main business, but did not complete a survey, whilst eight companies did not respond to calls. The 15 Indian vermiculture companies that completed the survey and provided details are distributed across the country (Fig. 1). 




Fig. 1 Map of India indicating the location of earthworm suppliers included in Table 3 (Source: Google Maps).

In South Africa, two companies that did not farm worms, identified two additional vermiculture businesses in their area, which were then included in the analysis. Of the total non-respondents, two companies had gone out of business and five confirmed that worm farming was their main business, 
but did not complete a survey. The seven vermiculture companies that completed the survey are mainly located in Johannesburg and Cape Town (Fig. 2).

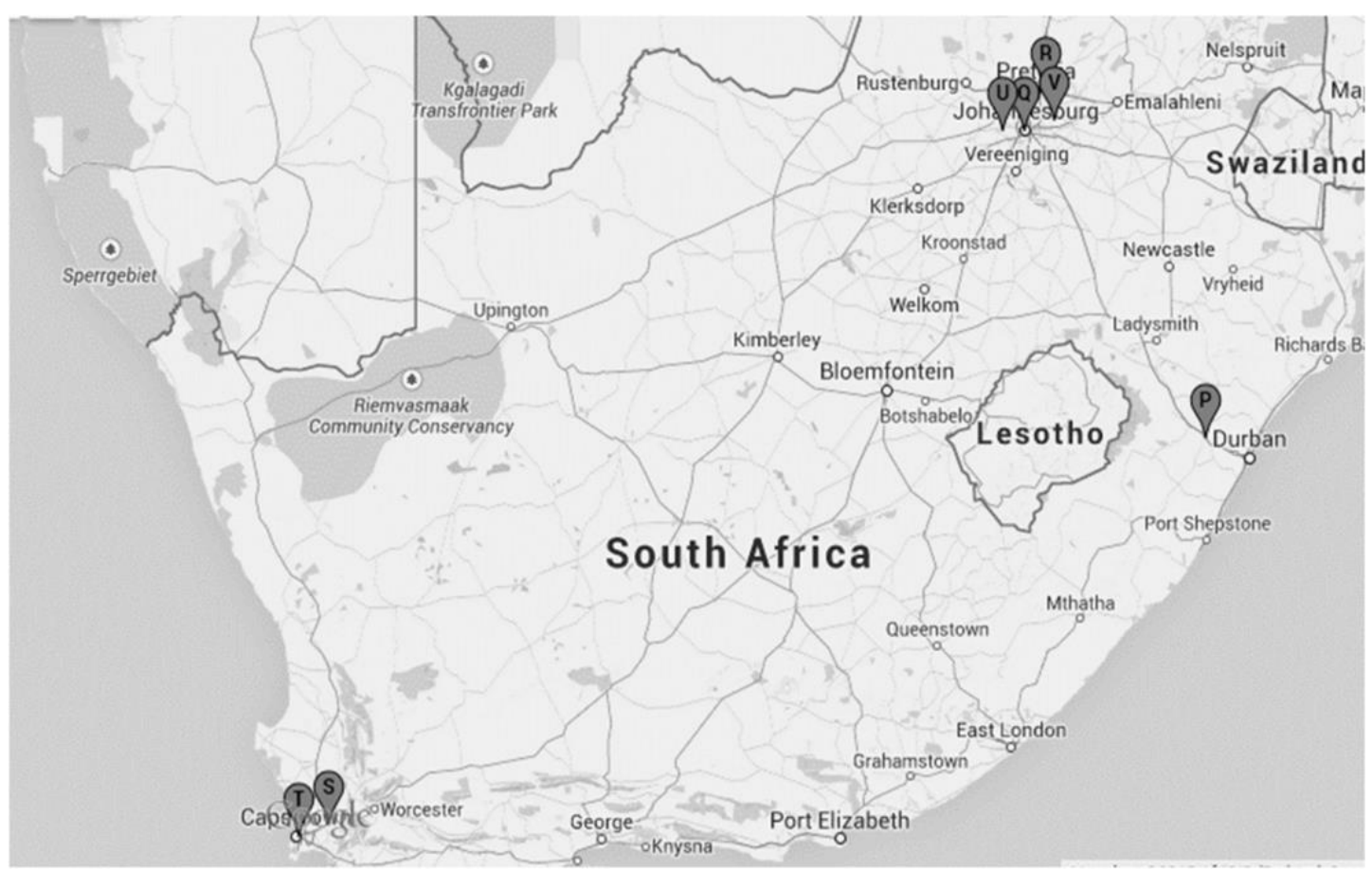

Fig. 2 Map of South Africa indicating the location of earthworm suppliers included in Table 3 (Source: Google Maps).

From this initial analysis, it appeared that the focus of the businesses contacted was predominately vermicomposting in South Africa and vermiculture in India. It was hypothesized that this was a function of market age and development. As worm-based markets develop, vermicomposting becomes an establish process which increases the demand for composting worms, therefore vermiculture becomes the dominant businesses.

The South African businesses were easier to contact, due to more internet-focused business strategies. Most of the large companies in both countries included a web-based communication strategy e.g. Skype, Facebook, Twitter. However, some companies had limited internet access and were not using these types of communication effectively, which was thought to have negatively influenced the current survey response rate. It was assumed that language was not a barrier for this survey, however some problems occurred when contacting companies in rural India by telephone, but his was overcome through clear communication.

These results confirm that there are sizable vermiculture markets in both India and South Africa. They therefore represent potentially favorable countries for the large-scale adoption of worm-based organic waste processing technologies, but only if their composting worm supply capabilities are large enough.

\subsection{Market analysis}

The hypothesis being explored in this paper is that the availability of composting worms is the reason for the lack of adoption of worm-based organic waste processing technologies. The supply capabilities in both countries were therefore explored via market analysis. 


\subsubsection{Indian market}

In India, all of the vermiculture companies $(n=15)$ were classified as large-scale i.e. were able to supply $>50 \mathrm{~kg}$ live worms per month (Table 3 ). Their worm production capacity varied from 100 to $50,000 \mathrm{~kg}$ per month, whilst 11 companies stated that they could supply $1000 \mathrm{~kg}$ or more per month. Except for one, all companies had been trading for between five and 19 years.

Table 3 Summary of questionnaire survey results from India and South Africa. (A dash indicates that information was not supplied). The geographical location of each company within India and South Africa is mapped in Figs. 1 and 2.

$\begin{array}{cllll}\begin{array}{c}\text { CompanyEarthworm } \\ \text { species }\end{array} & \begin{array}{l}\text { Species availability Production } \\ \text { (single/mixed) }\end{array} & \begin{array}{l}\text { Cost } \\ \text { capacity } \\ (\mathrm{Kg} / \text { month) }\end{array} & \begin{array}{l}\text { Cocoon } \\ (\mathrm{US} \$ / \mathrm{Kg})\end{array} & \text { availability }\end{array}$ Export experience

India

\begin{tabular}{|c|c|c|c|c|c|c|}
\hline A & $\mathrm{Ef}, \mathrm{Ee}$ & Single/Mixed & 1000 & - & Yes & No \\
\hline B & $\mathrm{Ef}, \mathrm{Pe}$ & Mixed & 100 & 15 & Yes & No \\
\hline C & Ef & Single & 50,000 & 8 & Yes & No \\
\hline D & Ee & Single & 9000 & $5-40$ & Yes & No \\
\hline$E$ & Ef & Single & - & 8.30 & No & No \\
\hline $\mathrm{F}$ & $\mathrm{Ef}$ & Single/Mixed & $\begin{array}{l}1000 \text { (500 from } \\
\text { each species) }\end{array}$ & 10 & No & - \\
\hline G & Ef & Single & 2000 & 41.50 & No & No \\
\hline $\mathrm{H}$ & $\mathrm{Ee}$ & Single & Limitless & 8.30 & No & Malaysia, Japan \\
\hline I & - & - & $\begin{array}{l}\text { Depends on the } \\
\text { request }\end{array}$ & 15 & Yes & No \\
\hline J & $\mathrm{Ee}, \mathrm{Ef}$ & Single/Mixed & 300 & 10 & No & - \\
\hline K & $\mathrm{Ef}$ & Single & 1000 & 8.50 & Yes & No \\
\hline L & Ef & Single & 3000 & 4.25 & No & Afghanistan \\
\hline M & $\mathrm{Ee}, \mathrm{Ef}$ & Single/Mixed & 1000 & 9 & Yes & $\begin{array}{l}\text { Malaysia, } \\
\text { Singapore, Italy, } \\
\text { Thailand }\end{array}$ \\
\hline $\mathrm{N}$ & $\mathrm{Ef}$ & Single & $>1000$ & 5.80 & No & No \\
\hline 0 & Ef, $\mathrm{Lr}$ & - & $\begin{array}{l}1000 \text { (500 from } \\
\text { each species) }\end{array}$ & 16 & No & - \\
\hline
\end{tabular}

South Africa

$\begin{array}{lllllll}\text { P } & \text { Ef } & \text { Single } & - & 47-66 & - & - \\ \text { Q } & \text { Ef } & \text { Single } & 20 & 56 & \text { Yes } & \text { Botswana }\end{array}$




\begin{tabular}{|c|c|c|c|c|c|c|}
\hline & $\begin{array}{l}\text { Earthworm } \\
\text { species }\end{array}$ & $\begin{array}{l}\text { Species availability } \\
\text { (single/mixed) }\end{array}$ & $\begin{array}{l}\text { Production } \\
\text { capacity } \\
\text { (Kg/month) }\end{array}$ & $\begin{array}{l}\text { Cost } \\
\text { (US\$/Kg) }\end{array}$ & $\begin{array}{l}\text { Cocoon } \\
\text { availability }\end{array}$ & Export experience \\
\hline \multicolumn{7}{|c|}{ India } \\
\hline$R$ & Ef & Single & 50 & 90 & Yes & $\begin{array}{l}\text { Namibia, Botswana, } \\
\text { Zambia }\end{array}$ \\
\hline$S$ & Ef & Single & 50 & 90 & Yes & No \\
\hline $\mathrm{T}$ & Ef & Single & 200 & 56 & No & $\begin{array}{l}\text { Tanzania, Botswana, } \\
\text { Namibia, Lesotho, } \\
\text { Ugandan }\end{array}$ \\
\hline$u$ & Ef, Ee & Single & 500 & 25 & No & No \\
\hline$V$ & Ef & Single & 2300 & 15 & Yes & $\begin{array}{l}\text { Zambia, Nambia, } \\
\text { Tanzania }\end{array}$ \\
\hline
\end{tabular}

Earthworm species: E. fetida (Ef), E. eugeniae (Ee), P. excavatus (Pe), L. rubellus (Lr)

Eisenia fetida was the most widely supplied species; the other species available were Eudrilus eugeniae, Perionyx excavatus and Lumbricus rubellus (Table 1). Eight companies sold single species, whilst four companies stated that they could provide worms as single or mixed species, depending on request. One company farmed only mixed, whilst a further two companies did not provide details of the types of worms available. Eleven companies stated that their worms have been independently verified by experts. The species of worms farmed is not surprising as it is known that $E$. fetida, $E$. eugeniae and $P$. excavatus have been used successfully for vermicomposting in India for over 30 years (Kale, 2011). The cost of the worms varied from US\$ 4.25 to 41.50 per $\mathrm{kg}$, with five companies charging less than US\$10 per $\mathrm{kg}$. Seven companies were able to supply cocoons, whilst only two of these were able to provide details of their production capacity, which were 5 and $9 \mathrm{~kg}$ per month. Also, three companies gave a price for their cocoons, which varied from US\$ 1 to 40 per $\mathrm{g}$.

Although a majority of their business was in the local area, 11 of the Indian companies had experience of transporting live earthworms to other cities or regions. Three companies had previously exported worms to other countries such as Malaysia, Japan, Afghanistan, Singapore, Italy and Thailand. Although these companies had exported beyond Asia, there was no shared customer base with the South African companies (Section 3.1.2), meaning each market studied was independent of the other. The respondent companies stated that it would take between $48 \mathrm{~h}$ and 10 weeks to fulfil an order of $20 \mathrm{~kg}$. A majority of the responding companies $(60 \%)$ stated that production capacity could be increased depending on demand. Five companies predicted that production could be doubled, whilst one company projected to increase their production by 2.5 times. A further three companies projected to increase production by three-fold or more. The survey results from India are summarized and presented in Table 3.

\subsubsection{South African market}

Vermiculture businesses in South Africa were a mixture of small scale producers (four could supply $50 \mathrm{~kg}$ per month) and large-scale producers (three companies). These companies had been trading for between five and thirty years. This is approximately the same as in India, so it would seem that a business focus on vermicomposting is not a function of the age of the market, but is demand driven. The large-scale vermiculture businesses supply capacity varied from 200 to $2300 \mathrm{~kg}$ per month, with 
only one company able to supply over $1000 \mathrm{~kg}$ per month. In small scale vermiculture business, the cost of worms varied from US\$ 47 to 90 per $\mathrm{kg}$, compared with US\$15 to 57 per $\mathrm{kg}$ for large-scale producers, which demonstrated economies of scale. Additionally, companies offered a discount for large orders, although this was not explored in the survey.

E. fetida was also the most common worm species grown in South Africa (Table 1). One of the large suppliers produces a mixture of E. fetida and E. eugeniae, whilst the other two companies supply only E. fetida (Table 1). All earthworm species were reported to have been independently verified by experts. All companies were able to supply cocoons, although none were able to provide a price for this. Two of the small scale and two of the large-scale producers had experience of exporting to neighboring African countries such as Botswana, Lesotho, Namibia, Tanzania, Uganda and Zimbabwe. Of the larger companies, two were able to supply cocoons at a cost of US\$2 $25 \mathrm{per} \mathrm{kg}$ mixed with vermicompost, whilst another stated that it would cost US\$10 per $100 \mathrm{~g}$ of cocoons. These companies projected that they could increase their worm production by two to ten-fold depending on demand. The survey results from South Africa have been summarized and presented in Table 3.

\subsubsection{Comparison of markets}

The price of worms was lower in India compared with South Africa. Five companies in India charged less than US\$ 10 per $\mathrm{kg}$ of worms, whilst the lowest price recorded in South Africa was US\$15 per kg of worms. This difference was possibly due to the strength of their currencies compared to the US\$ and the differences in the cost of living in each country. Both countries showed similar international export experience of worms. Overall, this study suggests that India has a larger vermiculture market compared with South Africa, whilst vermiculture businesses have been longer established in South Africa. This is thought to be due to the length of time each country had been exposed to this technology. In India, research on worms and their importance in nutrient cycling started over five decades ago (Nijhawan and Kanwar, 1952). However, the first efforts to use earthworms for waste management in India begin in 1978 at the University of Agricultural Science, Bangalore (Kale, 2011). Thereafter, numerous studies were conducted (e.g. Kale et al., 1982; Kale, 2004: Kaushiik and Garg, 2004; Garg et al., 2006; Suthar and Singh, 2008; Suthar, 2009) and awareness of vermiculture and vermicomposting was rapidly developed throughout the country allowing India to become one of the major vermicompost producers in the world (Kale, 2011). South Africa was another pioneering country in terms of vermicomposting (Munroe, 2004) and the current survey confirms that there is at least a 30-year history of vermiculture. Compared with India, less literature-related evidence is available for the South African vermicompost industry and its development. However, the vermiculture industry in South Africa has grown considerably in recent years, particularly in relation to the production of worms for waste management (DWAF, 2010; Voua Otomo et al., 2013).

The predominant worm species grown in both countries was E. fetida (Table 3 ) and as a majority of the worm farmers in both countries $(>70 \%)$ reported to have independently verified the worm species grown, this statement is thought to be correct. This is not surprising as E.fetida is commonly reported to be the most widely used vermicomposting worm (Domínguez and Edwards, 2011), therefore this study supports this statement. The reasons for the extensive use of this worm is that it is globally abundant, it can tolerate a large temperature range $\left(0^{\circ} \mathrm{C}-35^{\circ} \mathrm{C}\right.$ ) (Domínguez and Edwards, 2011), it reproduces rapidly through maturing quickly and producing high numbers of worms per cocoon (Table 1) and it tolerates handling and rough treatment (Munroe, 2004).

\subsection{Worm supply capacity}


Results suggest that capacity of worm production in India is over 70,000 kg per month, with the capacity to increase production to $150,000 \mathrm{~kg}$ per month. In South Africa, the capacity for worm production was over $3000 \mathrm{~kg}$ of worms per month, with an ability to increase this to $11,000 \mathrm{~kg}$ per month. All responding companies in India were large-scale worm suppliers, whilst more than half of those in South Africa were small-scale suppliers. Eleven companies in India stated that they could supply $1000 \mathrm{~kg}$ or more worms per month, whilst only one company in South Africa was able to fulfil that target.

Six to seven companies in both countries stated that they could supply worm cocoons, if there is a demand. However, the cocoon production capacity and prices were less established in both countries and only two to three companies could provide figures for this. The disadvantage of using cocoons in the bioconversion of organic waste, is that it takes time for them to hatch and to reach maturity. This means that there would be a lag-phase in the processing of waste typically of 45 days for E. fetida. An advantage of using cocoons is that they would be easier to transport due to their initial weight and robustness. It should be noted that none of the companies in either country had experience in transporting or supplying earthworm cocoons.

\subsection{Potential of scaling-up}

The initial aim of this study was to determine if worm supply would impact the scaling up of wormbased technologies, such as the Tiger Toilet. Assuming that an individual Tiger Toilet requires $2 \mathrm{~kg}$ of worms (e.g. Furlong et al., 2016), the survey results suggested that the Indian worm industry currently has the capacity to supply composting worms for 35,000 Tiger Toilets per month $(420,000$ per year), whilst South Africa has the current capacity to supply worms for 1500 Tiger Toilets per month $(18,000$ per year).

The $3000 \mathrm{~kg}$ of worms from South Africa have the ability to process the fecal waste from 15,000 people which equates to approximately 4 tonnes of feces per day and the current worm supply capacity in India could support processing of around 23 tonnes of fecal waste per day. Both countries have the potential to increase production of worms immediately, this would lead to the capacity to supply composting worms for 75,000 Tiger Toilets in India per month $(900,000$ Tiger Toilets per year) and 5500 Tiger Toilets per month in South Africa (66,000 per year). Currently 195 million households in India practice open defecation and 24 million households in South Africa practice either open defecation or have unimproved sanitation (based on the figures published by The World Bank, 2015; WHO/UNICEF, 2012). Both countries are huge potential markets for such a system. Furthermore, many of the companies in these countries have a history of exporting worms internationally, which means there is the potential for the global scaling-up of worm-based technologies from these markets.

The majority of the respondent companies (in both countries) stated that they have successfully transported worms to other regions of their country. However, live earthworm transport is a major concern and it should be undertaken rapidly to prevent undue stress and mortality. When introducing worm-based technology or taking one to scale, consideration of geographical location and local supply is highly recommended. Regarding cocoon production, limited information was gained from the current survey, due to the novelty of the product. Therefore, further research is required to assess this products business potential in the vermiculture world. It has been calculated from data provided by Domínguez and Edwards (2011) for E. fetida (the most common species identified in this study), that $100 \mathrm{~g}$ of cocoons could potentially yield $16 \mathrm{~kg}$ of adult worms, however, this process could take over 45 days (Table 1 ). The authors feel that cocoon production could be a novel business proposition in this market, which could lead to the accelerated global expansion of 
worm-based technologies due to ease of transport. This area still needs development in terms of separation methods, packaging and knowledge of cocoon hatchability, survival rate and time to reach maturity of the earthworm species of interest.

\section{Conclusions}

Even with the limited sample size in this study, it can be concluded that worm supply is not a barrier to either scaling-up or large-scale adoption of worm-based technologies in India and South Africa. It would appear that there is scope for worm production to assist development of worm-based systems throughout these and other countries in Asia and Africa. Although most companies could supply cocoons, currently this is less developed commercially. Yet, there is great potential to increase demand by encouraging cocoon production. Further studies are recommended to investigate the national vermiculture market in emerging economies such as China, and low-to middle-income countries where there is a huge potential for worm-based organic waste processing technologies.

Although this paper concluded that worm supply was not a barrier to large-scale implementation of worm-based technologies in these countries, it does not address why there has been limited uptake of vermicomposting as an organic waste management technique, further research is therefore required in areas such as technology transfer and appropriate business models.

\section{Acknowledgements}

The authors acknowledge the support of the Technology Strategy Board (United Kingdom) through an Innovation Voucher Round 6 and the International Federation of the Red Cross and Crescent, Geneva for funding this work.

\section{References}

Abassi et al., 2015Abassi S.A., Nayeem-Shah M. and Abassi T., Vermicomposting of phytomass: limitations of the past approaches, J. Clean. Prod. 93, 2015, 103-105.

Department of Environmental Affairs, 2012Department of Environmental Affairs, National Waste Information Baseline Report, 2012, Department of Environmental Affairs; Pretoria, South Africa.

Domínguez and Edwards, 2011Domínguez J. and Edwards C.A., Biology and ecology of earthworm species used for vermicomposting, In: Edwards C.A., Arancon N.Q. and Sherman R., (Eds.), Vermiculture Technology: Earthworms, Organic Waste and Environmental Management, 2011, CRC Press; Boca Raton, 27-38.

DWAF, 2010DWAF, Vermiculture Strategy for the Hartbeespoort Dam Integrated Biological Remediation Programme: Prepared by Ecowaste Management on Behalf of the Department of Water Affairs and Forestry and Rand Water, 2010, Department of Water Affairs and Forestry; South Africa.

Edwards, 2011Edwards C.A., Introduction, history, and potential of vermicomposting technology, In: Edwards C.A., Aracon N.Q. and Sherman R., (Eds.), Vermiculture Technology - Earthworms, Organic Wastes and Environmental Management, 2011, CRC Press; Boca Raton, 1-10.

Furlong et al., 2014Furlong C., Templeton M.R. and Gibson W.T., Processing of human faeces by wet vermifiltration for improved on-site sanitation, J. Water, Sanitation Hyg. Dev. 4, 2014, 231-239.

Furlong et al., 2015Furlong C., Gibson W.T., Templeton M.R., Taillade M., Kassam F., Crabb G., Godsell R., McQuilkin J., Oak A., Thakar G., Kodgire M. and Patankar R., The development of an 
onsite sanitation system based on vermifiltration: the 'tiger toilet', J. Water, Sanitation Hyg. Dev. 6, 2015, 608-613.

Furlong et al., 2016Furlong C., Gibson W.T., Oak A., Thakar G., Kodgire M. and Patankar R., Technical and user evaluation of a novel worm-based, on-site sanitation system in rural India, Waterlines 35 (2), 2016, 148-162.

Garg et al., 2006Garg P., Gupta A. and Satya S., Vermicomposting of different types of waste using Eisenia foetida: a comparative study, Bioresour. Technol. 97, 2006, 391-395.

Graham and Polizzotto, 2013Graham J.P. and Polizzotto M.L., Pit latrines and their impacts on groundwater quality: a systematic review, Environ. Health Perspect. 121, 2013, 521-530.

Hoonweg and Bhada-Tata, 2012Hoonweg D. and Bhada-Tata P., What a Waste: A Global Review of Solid Waste Management. Urban Development Series, 2012, The World Bank; Washington DC, USA.

Huang et al., 2013Huang K., Li F.S., Wei Y.F., Chen X.M. and Fu X.Y., Changes of bacterial and fungal community compositions during vermicomposting of vegetable wastes by Eisenia foetida, Bioresour. Technol. 150, 2013, 235-241.

Jiang et al., 2016Jiang L., Liu Y., Hu X., Zeng G., Wang H., Zhou L., Tan X., Huang B., Liu S. and Liu S., The use of microbial-earthworm ecofilters for wastewater treatment with special attention to influencing factors in performance: a review, Bioresour. Technol. 200, 2016, 999-1007.

Kadam et al., 2009Kadam A.M., Nemade P.D., Oza G.H. and Shankar H.S., Treatment of municipal wastewater using laterite-based constructed soil filter, Ecol. Eng. 35, 2009, 1051-1061.

Kale, 2004Kale R.D., The use of earthworms: nature's gift for utilization of organic wastes in Asia, In: Edwards C.A., (Ed), Earthworm Ecol., (second ed.), 2004, CRC Press; USA.

Kale, 2011Kale R.D., Origin and spread of vermicomposting in India: focus on sustainable agriculture, In: Edwards C.A., Aracon N.Q. and Sherman R., (Eds.), Vermiculture Technology: Earthworms, Organic Wastes and Environmental Management, 2011, CRC Press; Boca Raton, 453-466.

Kale et al., 1982Kale R.D., Bano K. and Krishnamoorthy R.V., Potential of Perionyx excavatus for utilizing organic wastes, Pedobiologia 23, 1982, 419-425.

Kaushik and Garg, 2004Kaushik P. and Garg V.K., Dynamics of biological and chemical parameters during vermicomposting of solid textile mill sludge mixed with cow dung and agricultural residues, Bioresour. Technol. 94, 2004, 203-209.

Komakech et al., 2015Komakech A.J., Sunbery C., Jonsson H. and Vinneras B., Life cycle assessment of biodegradable waste management systems for Sub-Saharan African Cities, Resour. Conservat. Recycl. 99, 2015, 100-110.

Lalander et al., 2015Lalander C.H., Komakech A.J. and Vinnerås B., Vermicomposting as manure management strategy for urban small-holder animal farms - Kampala case study, Waste Manage. 39, 2015, 96-103.

Li et al., 2009Li Y.S., Xiao Y.Q., Qiu J.P., Dai Y.Q. and Robin P., Continuous village sewage treatment by vermifiltration and activated sludge process, Water Sci. Technol. 60, 2009, 3001-3010.

Lim et al., 2014Lim S.L., Wu T.Y., Lim P.N. and Shak K.P.Y., The use of vermicompost in organic farming: overview, effects on soil and economics, J. Sci. Food Agri. 95, 2014, 1143-1156. 
Lim et al., 2015Lim P.N., Wu T.Y., Clarke C. and Daud N.N.N., A potential bioconversion of empty fruit bunches into organic fertilizer using Eudrilus eugeniae, Int. J. Environ. Sci. Technol. 12 (8), 2015, 2533-2544.

Lim et al., 2016Lim S.L., Lee L.H. and Wu T.Y., Sustainability of using composting and vermicomposting technologies for organic waste biotransformation: recent overview, greenhouse gases emissions and economic analysis, J. Clean. Prod. 11, 2016, 262-278.

Munroe, 2004Munroe G., Manual of On-Farm Vermicomposting and Vermiculture, 2004, Organic Agriculture Centre; Canada.

Nijhawan and Kanwar, 1952Nijhawan S.D. and Kanwar J.S., Physico chemical properties of earthworm casting and their effects on the productivity of soil, J. Agri. Sci. 22, 1952, 357-373.

Singh et al., 2011aSingh R.P., Singh P., Araujo A.S.F., Ibrahim M.H. and Sulaiman O., Management of urban solid waste, urban solid waste: vermicomposting a sustainable option, Resour. Conservat. Recycl. 55, 2011a, 719-729.

Singh et al., 2011bSingh R.P., Embrandiri A., Ibrahim M.H. and Esa N., Management of Biomass residues generated from oil palm mill; vermicomposting a sustainable option, Resour. Conservat. Recycl. 55, 2011b, 423-434.

Sinha et al., 2010Sinha R.K., Herat S., Bharambe G. and Brahambhatt A., Vermistabilization of sewage sludge (biosolids) by earthworms: converting a potential biohazard destined for landfill disposal into a pathogen-free, nutritive and safe biofertilizer for farms, Waste Manage.

Res. 28, 2010, 872-881.

Suthar, 2009Suthar S., Vermicomposting of vegetable-market solid waste using Eisenia fetida: impact of bulking material on earthworm growth and decomposition rate, Ecol. Eng. 35, 2009, 914920.

Suthar and Singh, 2008Suthar S. and Singh S., Vermicomposting of domestic waste by using two epigeic earthworms (Perionyx excavatus and Perionyx sansibaricus), Int. J. Environ. Sci. Technol. 5, 2008, 99-106.

The World Bank, 2015The World Bank, Data: Indicators, 2015 http://data.worldbank.org/indicator, (Accessed 26 February 2015).

Voua Otomo et al., 2013Voua Otomo L., Voua Otomo P., Bezuidenhout C.C. and Maboeta M.S., Molecular assessment of commercial and laboratory stocks of Eisenia Spp. (Oligochaeta: Lumbricidae) from South Africa, Afr. Invertebr. 54, 2013, 499-511.

WHO/UNICEF, 2012WHO/UNICEF, Progress on Drinking Water and Sanitation: 2012 Update, 2012, WHO/UNICEF; USA.

Wu et al., 2014Wu T.Y., Lim S.L., Lim P.N. and Shak K.P.Y., Biotransformation of biodegradable solid wastes into organic fertilizers using composting or/and vermicomposting, Chem. Eng. Trans. 39, 2014, 1579-1584.

Yadav and Garg, 2011Yadav A. and Garg V.K., Industrial wastes and sludge management by vermicomposting, Environ. Sci. Biotech. 10, 2011, 243-276. 
Zhang et al., 2013Zhang W., Hendrix P.F., Dame L.E., Burke R.A., Wu J., Neher D.A., Li J., Shao Y. and Fu S., Earthworms facilitate carbon sequestration through unequal amplification of carbon stabilization compared with mineralization, Nat. Commun. 4, 2013, 2576.

Zhao et al., 2010Zhao L.M., Wang Y.Y., Yang J., Xing M.Y., Li X.W., Yi D.H. and Deng D.H., Earthwormmicroorganism interactions: A strategy to stabilize domestic wastewater sludge, Water Res. 44, 2010, 2572-2582.

Footnotes

1 Calculated using figures of $300 \mathrm{~g}$ feces generated per person per day, $42 \%$ of the global population using unimproved sanitation and a current world population of 7.5 billion.

2 Web of Science search on 3/12/2016 search terms used was vermicomposting.

Accepted Date: 26 June 2017 